\title{
Cultural Confidence and China's International Discourse Power
}

\author{
Ming Guo \\ Guangdong Polytechnic of Science and Technology, Zhuhai, 519000, China \\ Macao University of Science and Technology, 999078, Macau \\ guodream@163.com
}

\begin{abstract}
The international discourse power of emerging countries is at a disadvantage state. To build cultural confidence is to find a discourse symbol that can overcome the shortcomings of modern society and the conflict between world and civilization from the renewal and transformation of traditional Chinese civilization. From the perspective of modern Chinese modern civilization, the advantages of development are transformed into speech advantages and persuasiveness. Promoting confidence in Chinese discourse in new global governance through the global Chinese story and the concept of a community of shared future for mankind, 1) the first is to figure out what kind of culture we should be confident; 2) the second is to understand how to disseminate our culture of confidence and enhance international discourse; and 3 ) the third is a strategy for people abroad and at home to take emphasis on cultural transmission.
\end{abstract}

Keywords-International discourse power; Discourse system; Cultural confidence; Community of human destiny

\section{INTRODUCTION}

International discourse power is a new kind of power in international communication, it is the game between the interests of countries and the projection of their comprehensive strength in international relations, it is an important representation and support of a country's soft power. The concept of "discourse power" originally came from the theory of French sociologist michel foucault on the relationship between discourse and social power. In December 1970, foucault put forward the famous proposition that "speech is power and man gives himself power through discourse". He thinks that discourse is not only a symbol of thinking and communication tools, also is the struggle of the people. This gives the discourse which is without any ideological color right and interest function [1].

\section{WHY CHINA NEEDS TO IMPROVE CULTURAL CONFIDENCE?}

Comrade xi jinping pointed out: "To enhance the country's cultural soft power, we must strive to increase the international discourse power. We need to strengthen the international communication capacity, carefully build a foreign discourse system and give full play to the role of emerging media, We will enhance the creativity, charisma and credibility of foreign discourse, and tell a good Chinese story"[2]. President xi jinping pointed out at the 95th anniversary of the founding of the communist party of China (CPC): "Cultural confidence is a more basic, broader, deeper confidence." In the party's 19 report, it is further emphasized: "We will strengthen cultural confidence and promote the prosperity of socialist culture". The soft power of Chinese culture refers to the cultural attraction formed by the ancient Chinese civilization in the process of modernization in the era of globalization, which can penetrate the ancient and modern times and integrate the Chinese and foreign cultures, This kind of Chinese cultura attraction comes from three aspects: The cultural appeal of the ancient Chinese civilization; Cultural creativity in the course of modern China's modernization and Global China's cultural credibility in international governance.

\section{A. It is an inevitable requirement for cultural power to strive for international discourse power}

Since the 2008 financial crisis, China has gradually come to the center of the international stage. The home-field diplomacy since 2012 has fully demonstrated the style of China's majorcountry diplomacy, Also let more and more countries begin to pay close attention to "Beijing time" attention and efforts to adapt to seek the mystery of the "Beijing consensus", appreciate the Chinese language and the charm of "Chinese culture", search for the miracle of "Chinese way" and "China's development", The west and developing countries more urgently need to understand how the "development path" with Chinese characteristics is different from the west. From "standing up" to "getting rich", China now needs "getting stronger". To put it bluntly, "when you have strings in your heart and money in your hand, you need to have a voice in your mouth."[3]. Zhao kejin also said "Don't think that the International discourse power depends solely on the moral level and cultural strength. As long as the cultural and moral level of a country is revitalized, International discourse power will be enhanced." [4]. To be convinced the world cultural power, one must make a deep study of success in the Chinese civilization make contributions to the world the idea of unique ideas and practical significance, and make Chinese words and values can be widely accepted as an international society. 


\section{B. In the era of globalization, we need to build our own voice}

We will build an international discourse platform featuring a community of Shared future for mankind and enhance China's voice in international affairs. The report of the 18th CPC national congress was first submitted: "It is a world where countries are linked with and dependent on one another at a level never seen before. Mankind, by living in the same global village in the same era and on the same earth where history and reality meet, has increasingly emerged as a community with a shared future in which everyone has in himself a little bit of others." Once again, xi systematically expounded the rich connotation and value of the idea of a community of Shared future for mankind and wrote the community of Shared future for mankind into the constitution of the CPC in Part xii of nineteen ninety-nine, Special emphasis is placed on "building a community of Shared future for mankind, building a world of lasting peace, universal security, common prosperity, openness, inclusiveness and cleanliness."

Nowadays, globalization has increasingly presented the fate of all countries on the planet in a chain state of "one glory, one loss", Social polarization caused by global overcapacity, ethnic conflicts brought about by cross-border migration flows and religious struggles brought about by the return of global religion, Some countries are beginning to celebrate populism, nationalism, protectionism and even isolationism. The mainstream international society formed in modern times is in danger of fragmentation [5]. In the face of such an international environment, general secretary xi jinping has elaborated on how to build a community of Shared future for mankind with five "important" systems, It is to respect each other and to negotiate equally, Firmly abandon cold war thinking and power politics; We should resolve disputes through dialogue and differences through consultation; We should work together to promote trade and investment liberalization and facilitation; We should respect the diversity of world civilizations; We must protect the earth home on which human beings live. Xi jinping, general secretary of the community of human destiny is proposed for the global ecological harmony, international peace, change the global governance system, build a global new order of justice all contribution to the Chinese wisdom and solutions in China.

\section{WHAT KIND OF CULTURE SHOULD WE BE CONFIDENT?}

Culture is an important system for a country and a nation to survive and define its identity, including the writing, language, clothing, festivals, arts, literature, memorial activities and other fields, it interprets and defines the meaning of culture. The author of confusion in what form is the traditional Chinese culture to spread all over the world in what sense? What is our current "socialist culture"? What kind of cultural confidence is "cultural confidence"? What is the theoretical value of the community of Shared future of mankind? This requires us to clarify the state of Chinese culture after thousands of years. What is the relationship?

\section{A. The state of local Chinese culture}

At an international academic conference to mark the 2565th anniversary of the birth of Confucius, xi said, "China's excellent traditional culture can provide useful enlightenment for people to understand and transform the world, it can provide useful enlightenment for governance, and it can also provide useful inspiration for moral construction. And our national governance system today, It is the result of long-term development, gradual improvement and endogenous evolution on the basis of China's historical inheritance, cultural tradition and economic and social development."[6]. "Without the inheritance and development of civilization and the promotion and prosperity of culture, there will be no realization of the Chinese dream." [7] At present, there are three types of local Chinese culture: ethical culture, political culture and economic culture.

First, Ethical culture: from Chinese traditional culture.

Chinese traditional culture is dominated by Confucianism. In Confucian culture, home and country are of the same quality. The home is the miniature form of the state, and the state is the expanded form of the home. The relationship between individuals and countries is a reasonable extrapolation of the relationship between individuals and families. Parents are like Kings, brothers and sisters are like superiors, wives are like peers, brothers and sisters are like inferiors, and children are like subjects. This kind of ethical emotion applied to the family is applied to the country. In the family, filial piety is paid to parents. They are engaged in political activities, but they are consistent with the spirit of ethics. Therefore, it is called ethical culture.

Second, Political culture: from a long - term planned economy.

New China has entered a planned economy. Politics occupies the "central position" of the whole social structure. Political power controls all areas of social life, and economic activity in a sense operates according to political power relations. If we say that in the "past", the spirit of ethics is connected with political activities, this period is just the opposite, that is, the spirit of politics is connected with moral activities. For a while, the family was not organized by kinship, but by political relations.

Third, Economic culture: from the market economy.

This kind of culture is the product of market economy completely, also be the mainstream culture of market economy period. This culture is based on the overall abandonment of traditional ethical culture and political culture in the planned economy period. The basis of human nature of this culture is the theory of material interest driving the evil of human nature -- the motivation that dominates people's activities. In the end, it is to seek the benefits of material things. Its core is the optimization principle of efficiency and benefit. Its value orientation is absolute market value orientation. 


\section{B. Western culture infiltrates into China}

Over 500 years since Columbus discovered the new world in 1492, the west has gradually changed from a frontier town to the center of the world. Especially in the 19th century, the collapse of the Oriental tributary system and the formation of the world market system gradually formed an international order dominated by the "western center". China has always been excluded from this order, and western culture entered China in different forms when China's doors opened again.

First, Western classical culture.

Some scholars call western classical culture "sacred sex culture". It is composed of three spiritual frameworks: one is the rational spirit of Greek philosophy; the second is the Hebrew religious spirit; Third, the legal spirit of Rome. Whitehead said, "twenty-five hundred years of western philosophy is but a series of footnotes to Plato." This kind of classical sex culture has been "transformed" (such as religious reform) or "absorbed", but its spiritual temperament has been extended to this day in certain forms.

\section{Second, Modernity culture.}

Modernity culture refers to a new form of culture formed on the basis of denying the classical sacredness culture, starting from the Renaissance and the enlightenment movement. It is now customary to define it as "rationalism and humanism". It is the spiritual pillar of modern industrial society. It supported the formation of the western capitalist world. In less than a hundred years of class rule, the bourgeoisie has created more productive forces than the entire productive forces created in all previous centuries. The development of the productive forces has made the mankind obtain the glorious social material and spiritual wealth.

\section{Third, Postmodern culture}

It originates from the modernity culture, which is the inevitable result of the development of the modernity culture, but it is by no means "inheriting" the modernity culture. It is "anti-traditional", but not against "all cultural traditions", but mainly against "modernity culture". Post-modernity culture advocates the thinking of the vagrant, the end of philosophy, the dissolution of the center, the collapse of the foundation, Rational meteorology, the subversion of structure, the reduction of value, the diversification of perspective, the game of interpretation, the countertradition of methods and so on.

\section{The state and characteristics of the model after the integration of Chinese and western cultures}

The Chinese civilization now faces both the inheritance of traditional culture and the challenge of today's multiculturalism and values. We have both "righteousness and propriety wisdom letter" as the representative of Confucianism, and formed in the revolution of the communist party of China after the founding of "serve the people", "seek truth from facts" and "mass line" culture of the Chinese revolution; At the same time, on the premise of inheriting the basic principles of marxism, the socialist culture with Chinese characteristics is constantly improved in practice in combination with China's reality. Now after the modern trend of decentralization, the mainstream values has been the impact of the traditional mainstream values, cross docking, foreign is greater than the native, the characteristics of innovation than inheritance.

\section{First, Interlocking cultures}

The western post-modernity culture is connected with the Chinese traditional ethical culture. China's economic culture is connected with western modernity culture. The rest of China's political culture and the western classical sex culture have a lot of affinity. It's a wonderful cultural landscape. The first step in China's rise must be the strong return of traditional culture, which has been gradually revitalized and is being strongly confronted with western civilization. This is a big ferment era, from the point of view of big history, complete with a super Chinese civilization, the Chinese maintained a valuable spirit of globalism, Chinese culture is the farthest distance from the narrow nationalism. At the same time, the humanist values of Confucianism and Taoism make Chinese civilization meet the needs of the integration of human society in the new era. The Chinese people pursue harmony between man and nature, the ancient Chinese people pursue world peace and world harmony. Chinese civilization has the spirit of innovation and reform that is "new, new, and new". There is the theory of "harmony without uniformity" of multiple co-existence of civilization. The harmonious spirit between man and nature, society and ecology. And the world view of Chinese civilization and peaceful cosmopolitanism. We have the great ideal of selfcultivation, family unity, governance and peace. China's rise has also ushered in a new era of human civilization.

\section{Second, Foreign culture is greater than native culture}

General secretary xi jinping proposed the idea of "building a community of Shared future for mankind" in the 19th CPC national congress report, he said: "We should respect the diversity of world civilizations, and promote exchanges among civilizations beyond their estrangement, mutual learning among civilizations over their conflict, and coexistence among civilizations over their superiority," How to "build a community of Shared future for mankind"? It is crucial to resolve the conflict between civilizations and achieve mutual learning and integration among civilizations. The unique spirit of Chinese civilization can provide important value support for different civilizations to achieve rational communication, mutual learning and integration[8] It is that first time since the discovery of the country that American and American country have undergone 500 years of expansion, plunder, war, Established the world colonial system and the formation of the world market system, Through the printing of machines and the issuance of money, the establishment of the press and the monopoly of public opinion, the whole non-western civilization is enticed to join the discourse system based on the so-called "freedom and democracy"[9] In international exchanges, the west has gradually monopolized the world in terms of discourse power through military, economic, diplomatic and cultural means. Wang furen, a scholar, pointed out that "western discourse" and "Chinese discourse" are parallel words. Their relationship is independent of each other, not opposed to each other. It is their independent development, not the elimination of long, mutual oppression and mutual subversion. [10] Therefore, he believes that "western 
discourse" and "western discourse hegemony" should be strictly distinguished. The non-hegemonic nature of "western discourse" may affect our thoughts and feelings, as it satisfies the unattainable satisfaction of the inherent cultural tradition. "Western discourse has the potential to be our" hegemonic discourse, also could not be our hegemonic discourse, they can become our hegemonic discourse, is not the word itself, but we accept it [11]. Therefore, only by strengthening the understanding of our own culture and enriching the explanatory power of our own culture to the real problems can we fundamentally maintain and improve the appeal of Chinese discourse.

\section{Third, Innovation is better than inheritance}

From the perspective of human history, the rise of great powers will certainly bring forward cooperation initiatives and values that will guide the future of the world. One Belt And One Road and the idea of a community of Shared future for mankind behind it carry this mission. The community of human destiny has become the core idea of new international relations and new global governance advocated by China. [12] Since taking office, President xi jinping has taken the initiative of publishing signed articles in the newspapers and periodicals of the visiting countries, which is an innovation and a pioneer for China's top leaders to publish articles in overseas media before their visits. In 2014, 2015 and 2017, xi jinping paid state visits to 54 countries and published 32 signed articles. Among them, the byline article is rooted in the historical and current relations between the two countries. By integrating the local people's familiar stories, Citing the proverb saying the two countries, verses, leaming, supplemented by details and data, in many areas of common ground between the two countries and convergence, foil theme of win-win cooperation, "xi diplomacy" is unique in the concrete embodiment of written style and philosophy. [13] With the rapid rise of China, the world's curiosity about Chinese characteristics and the road of China is mixed with confusion and concerns, The Chinese government has carried out active media diplomacy, home diplomacy, head of state diplomacy and other official diplomacy to enhance the export of Chinese culture and the ability to set the agenda. At the same time, the Chinese government is more and more desperate for foreign people to understand, before the trip, the sighting journal articles by passing friendly sincere culture, warm the heart of the story, show the valid data in the development of China, Enhance the cultural identity and mutual understanding between countries, and show the diplomatic demeanor and bearing of great powers

\section{HOW CAN WE SPREAD OUR CULTURE OF CONFIDENCE AND ENHANCE INTERNATIONAL DISCOURSE?}

\section{A. How to show a good Chinese story?}

On November 19, 2014, professor wang yimian of renmin university of China put forward the view of "three Chinese stories" at the symposium on "telling the Chinese story well" hosted by comrade liu yunshan, member of the standing committee of the political bureau of the CPC central committee He believes that "telling a good China story" is to tell a good story about the revival, transformation and innovation of ancient Chinese civilization in the era of globalization. To tell a good Chinese story, it should be based on the concept of "three chinas" in the new era, including three core contents: First is the story of the revival and transformation of traditional Chinese civilization (civilized China), The traditional Chinese cultural five-element story is a meta-story composed of cultural concepts, cultural rituals, cultural symbols, cultural products and cultural beliefs; Second is the story of modern China's modernization (nation state), The story of the five modernizations of modern China is a meta-story composed of industrial modernization, agricultural modernization, scientific and technological modernization, military modernization and national governance modernization; Third is the story of global China's globalization (community countries), The story of global China: One Belt And One Road is a story of policy communication, facilities, trade, finance and people. Tell the story of the revival and transformation of traditional Chinese civilization (civilized China). Speak good story of modern China's modernization (national), including the industrial modernization, agricultural modernization, the modernization of science and technology, military modernization, modernization of governance of yuan story; Tell the story of China around the world, including the "five-way story" along the belt and road, international sports events and important international conferences.

\section{B. How to enhance the effectiveness of international communication?}

How is the discourse understood and accepted by the people of western countries? Does the content spread have the distinction of sequence, key point? Due to the differences between Chinese and western cultures, how to make Chinese discourse widely accepted by the international community is an urgent problem for China to fight for international discourse power.

The story of the revival and transformation of traditional Chinese civilization (civilized China) is to improve the national voice of cultural values in the international civil discourse space. The modernization story of modern China (nation state) is to improve the international political discourse power in the international official discourse space. The global China story is about raising the international voice of China's global governance in the international public discourse space. In traditional - modern - global story of China as the research object, in order to improve the cultural values international discourse, political discourse, the international voice of global governance as the goal, to improve the appeal of Chinese culture, Chinese culture creativity, the credibility of Chinese culture.

China's international voice not only meets the different needs of the international target audience, but also meets the needs of the rising China to communicate to the world. Dominated by Chinese WaiWenJu in 2013, the professional market research company to carry out China's global image survey, covers from the UK, us, South Africa, India, Russia, Brazil, the six wuzhou survey, 3017 people in the morning the public image of the Chinese people in foreign countries. According to the survey results, foreign people are generally interested in Chinese traditional culture and most of them know Chinese cultural symbols, such as martial arts, history, diet and 
traditional Chinese medicine. But for including the cognition of the Chinese government, Chinese philosophy advocated by the content of the evaluation of the three for China's development model, the vast majority of the public in China put forward the idea that don't know much, and there are also not interested in some political concepts have some misunderstanding[14]. Peng-fei xing in the 23 universities in different provinces of socialist core values for college students present situation has carried on the empirical study, college students' understanding of socialist core values and cognitive is sufficient, in the view of political mediation model found new liberalism due to cater to the students' simple liberal for identification, Democratic socialism is favored because its pragmatic and eclectic views satisfy college students' fantasy of an ideal and beautiful society [15]. Therefore, we find that the majority of foreign people agree with China's traditional culture and are unfamiliar with the rise of China and the concept of China. While the Chinese people (especially the young people) agree with the history of China and the rise of China, they are also impacted by western culture and have no clear understanding of the advantages of their own culture. Therefore, starting from the $5 \mathrm{~W}$ theory of communication science, different objects should be given some emphasis on the content of communication. To foreign people more should focus on China modern and contemporary culture, the spread of revolutionary culture, socialist culture, to the domestic people should be more focus on the return to Chinese traditional culture, the spread of the culture of innovation.

\section{Pursues a concept that is consistent with Chinese values and is recognized by the world}

China's cultural soft power is the western expression of the sinicization of the concept of soft power, is a with Chinese characteristics, the new expression, new concepts, new category can effectively avoid and eliminate cultural hegemony colour, can communicate, can experience, shareable. The thought and theory with Chinese characteristics, Chinese style and Chinese style need to be carried and conveyed with Chinese characteristics, Chinese style and Chinese style.

To establish China's theoretical research and discourse system, the most intense and crucial area of the discourse right debate is the political discourse right struggle. For a long time, the west has held the commanding height of the right to speak, and has been making speeches such as "freedom of speech", "democracy" and "human rights" to restrict the development of China's international space. In the 21 st century, when the old and the new order are merged, China urgently needs to find values and institutional designs that can be accepted by the world through its own culture and practice. Some scholars have pointed out that a lot of wisdom in ancient Chinese civilization can be a new concept of world order. For example, "tianya is like a neighbor" is the interpersonal relationship in the online world. "Wang dao benevolence policy" can correct the deviation between separation of powers and multi-party politics. "Integration by body" is the way to solve ideological opposition. "Live within your means and act within your means" is a balanced approach to the excessive expenditure of the "welfare state". "Unity of man and nature" is the philosophical expression of ecological protection. The "system of heaven under heaven" should be defined as a community of common destiny under heaven [16]. The extensive and profound Chinese philosophy has always solved the spiritual needs of The Times in the course of history. Since modern times, the language and many core concepts we use have been formed by the interaction between Confucianism, Buddhism and Taoism. [17]. But how to use the practice to prove its universality and can helps for, how to use simple language and stories in the broad international and domestic public consensus, this is an important problem facing the theoretical workers and controller. China advocates "human destiny community" the core idea of whether can with "global governance" as the core target of world order together to serve the human society, China has met a its own management system and the trend of combining the strategic opportunity of global governance, in such a great history node, How China internally to grasp the fate of the ethnic community itself, foreign handle with neighboring China, China with big countries, China and the world of human destiny community, are challenges and opportunities for China.

\section{V.CONCLUSION}

Although we put forward "human destiny community" to dialogue instead of cursing and confrontation, advocated "mutual trust and mutual benefit, equality and collaboration" rather than "alliance - containment", the world of the new idea of the new international relations, But the Chinese world dream how to combine the Chinese dream of the Chinese people, show the Chinese civilization, need to continue to segmentation and discusses theoretically the characteristics of Chinese culture and the differences between Chinese and western culture. How the Chinese cultural confidence into the people of the world to China, we need to continue to excavate the profound meaning of their own culture and powerful vitality to solve the problem, not only speak good story, We also need to use "One Belt And One Road" as the real case and the data to endorse China's roads and theories, from the name to the fact that China has the charm of the Chinese and Chinese culture, to the western center, to build a new international relationship and global governance that can be inclusive, accessible, accessible, and Shared.

\section{REFERENCES}

[1] Li shenming is vice President and researcher of the Chinese academy of social sciences. The western discourse system should be clearly judged, China, a think-tank, May 2013.

[2] During his 12th collective study in the political bureau of the communist party of China (CPC) central committee, xi emphasized building a strong socialist culture and strengthening the country's cultural soft power. December 30, 2013.

[3] Jiang Chong (the China institute of contemporary international relations in the economic security research center), Zhao Kejin (tsinghua university's then - Carnegie), director of the center for global speech included two beam cayin the international discourse power: the inevitable requirement of cultural power, China education, December 2011(11)

[4] Jiang Chong (the China institute of contemporary international relations in the economic security research center), Zhao Kejin (tsinghua university's then - Carnegie), director of the center for global speech included two beam cayin the international discourse power: the 
inevitable requirement of cultural power, China education, December 2011(11).

[5] Zhao kejin, the ideological background and theoretical orientation of the community of Shared future of mankind. Study times, April 2017(02).

[6] Xi jinping: The governance of China . Beijing: foreign language publishing house.2014.pp105.

[7] Xi jinping: The governance of China . Beijing: foreign language publishing house.2014.pp105.

[8] Li shenming is vice President and researcher of the Chinese academy of social sciences. The western discourse system should be clearly judged, China, a think-tank, May 2013.

[9] Yu mingsong deputy director of the Chinese culture teaching and research department of the central socialist college. Youth league final report February 2018(08).

[10] Wang Fu Ren "Western discourse" and Chinese contemporary culture. Literary criticism, January 2004(01).

[11] Wang yizhi is vice President of xi jinping institute of socialist ideology with Chinese characteristics in the new era. Qiushi network February 26, 2018.

[12] Yang hongyan, master of school of journalism and communication, tsinghua university, Zhou qingan, associate professor, school of journalism and communication, tsinghua university. A preliminary study on the media diplomacy of national leaders from the perspective of public diplomacy -- a case study of xi jinping's signed overseas articles. Excellent thesis of the fifth national seminar on foreign communication theory. In July 2017.

[13] Wu Xian Jun,Doctor's thesis of fujian normal university, Research on the construction of international discourse power in the context of China's peaceful development, In June 2015.

[14] Xing pengfei ,school of marxism, hunan normal university, An investigation on the status quo of college students' socialist core values identification and cultivation countermeasures, University education management, In March 2018(12-2).

[15] Huang renwei is vice President of Shanghai academy of social sciences, Fu yong is a researcher at the institute of international relations, Shanghai academy of social sciences, From the western order to the community of human destiny, Wen wei report January 2016(02).

[16] Chen xianhong, professor, school of journalism and information communication, huazhong university of science and technology, Tell a good review and prospect of Chinese stories in Chinese language, Foreign spread, In January 2017. 